\title{
Re-defining the Shakespearean Actor: Casting and Diversity at Shakespeare's Globe under Emma Rice and Michelle Terry
}

Miranda Fay Thomas

\section{(2) OpenEdition \\ Journals}

\section{Electronic version}

URL: https://journals.openedition.org/shakespeare/6048

DOI: $10.4000 /$ shakespeare.6048

ISSN: 2271-6424

Publisher

Société Française Shakespeare

\section{Electronic reference}

Miranda Fay Thomas, "Re-defining the Shakespearean Actor: Casting and Diversity at Shakespeare's Globe under Emma Rice and Michelle Terry", Actes des congrès de la Société française Shakespeare

[Online], 39 | 2021, Online since 17 May 2021, connection on 23 August 2021. URL: http:// journals.openedition.org/shakespeare/6048; DOI: https://doi.org/10.4000/shakespeare.6048

This text was automatically generated on 23 August 2021.

(c) SFS 


\title{
Re-defining the Shakespearean Actor: Casting and Diversity at Shakespeare's Globe under Emma Rice and Michelle Terry
}

\author{
Miranda Fay Thomas
}

A common notion in early modern society was that "totus mundus agit histrionem": "everyone is an actor". ${ }^{1}$ But as theatre history and criticism since the Renaissance era have shown, not everyone is given the privileged moniker of being a "Shakespearean actor". So what is this distinction; when, and why is it bestowed upon particular individuals? This essay considers how different actors and casting practices help to construct the way audiences view Shakespeare, his texts, his characters, and most importantly, his actors. My thinking is prompted by a variety of vexed and interconnected questions. What is a Shakespearean actor, and how is one defined? Who has traditionally been allowed to be one, and how has this term changed over time? And how is the process of being considered a "Shakespearean actor" different and more difficult for non-British, non-white, non-cisgender male, and/or disabled practitioners? These questions do not, of course, have clear answers. But the process of asking such questions helps to facilitate how traditional understandings of what it takes to be a "Shakespearean actor" are based in the perpetuation of inequalities found at the heart of British culture and are in danger of being replicated by theatrical institutions and artistic directors. As a focus, this article considers the casting practices at Shakespeare's Globe Theatre since 2016, and argues that, while representation is a crucial step towards equality, the casting of diverse actors is not enough to mitigate the histories of oppression and inequality faced by marginalised communities. Rather, theatre directors and producers must reconsider their role as story-tellers, and resist creating narratives which un-problematically replicate pre-existing, harmful stereotypes. 
2 Built as an historically-informed reconstruction combining elements of the first Globe (built in 1599) and the second Globe (built in 1614), since its 1997 opening the "new Globe" has frequently been a hub for theatrical experiments in original practices, ${ }^{2}$ or when it diverts from this - debates around what original practices is for and why it is or is not - important to modern audiences and practitioners. At the heart of these discussions is a conflict between a desire for "authenticity", and the practical considerations and needs of modern productions and their audiences. For instance, while the structure of the theatre was built with oak timber and fitted together with mortise and tenon joints rather than using structural steel, Shakespeare's Globe nevertheless provides a concrete floor for the groundlings to stand on because the open earth gets far too muddy; see also the modern need for lurid green fire exit signs (all the more important given that the first Globe burned down in 1613). Naturally, this desire to balance authentic practices with modern considerations and expectations is also applicable to casting, particularly in an age of increasing diversity. While for some people, Mark Rylance as Olivia in an all-male Twelfth Night might be the most quintessential Globe production which comes to mind, the majority of productions at the Globe do not use single-gender casting and create ensembles which reflect the more diverse society in which we live now.

This article focuses on casting practices at Shakespeare's Globe under the artistic directorships of Emma Rice and Michelle Terry, and uses two productions as case studies: Rice's Twelfth Night in 2017 and Terry's Hamlet in 2018. A year apart, both productions used casting to play with ideas about gender and sexuality, and both used casts which were racially diverse. Terry's Hamlet also included in the cast Nadia Nadarajah, an actor who is Deaf. ${ }^{3}$ I use these two productions to think about casting practices in modern productions of Shakespeare, and the discourse that surrounds such practices, to advocate for what I call "thoughtful diversity". By this, I mean not just ensuring diverse casting, but diverse casting which considers the optics of how diverse bodies are used to tell stories to predominantly white audiences.

Before I look at these two case studies in detail, I must first reflect further on the concept of the "Shakespearean actor" through three interlinked approaches: authenticity, ability and opportunity.

\section{Authenticity?}

5 The question of what makes an authentic Shakespearean actor actually prompts the question of authenticity itself. In fact, several questions emerge when interrogating the concept of "authenticity" in Shakespearean performance: what does it imply, what does it mean in a modern context, how far should we go to achieve it - and what might be lost by its pursuit? The notion of authenticity - paradoxically - is culturally contingent to particular ages, as new generations of critics, theatre-goers, and theatremakers re-evaluate the working definition of "original practices" as well as a more general and hazily undefined sense of what makes a Shakespearean production tonally authentic (that is, capturing a sense of the play as it may have been originally played and appreciated). In his introduction to Great Shakespeare Actors: From Burbage to Branagh, Stanley Wells nods to the evolutions within the theatrical tradition, noting the introduction of women to the stage, cross-gender casting, and the more recent attempts by companies to look backwards in an attempt at recreating the conditions of 
Shakespeare's original productions. ${ }^{4}$ Wells notes that "grown men have played female roles" as part of "original practice" productions at Shakespeare's Globe, but judges this as "inauthentic in that they do not cast boys in women's roles". ${ }^{5}$ This is just one example of many which prompts the question of whether is it possible (or even desirable) for a production to truly replicate "original practices", or whether any attempt at original practices is inherently flawed because it provides some level of "authenticity" (male actors playing female characters) but not others (young boys, rather than adult men, playing female characters).

One critical tension surrounding the performance of Shakespeare in the twenty-first century is that the notion of Shakespearean "authenticity" is at odds with the desire for greater representation in casting. Upon becoming Artistic Director of Shakespeare's Globe in 2017, Michelle Terry was noted for saying: "[o]riginal practice for me has limiting or almost pejorative connotations now because it implies that women can't be in the plays, and that's not going to happen". ${ }^{6}$ Terry, the first actor to become artistic director of Shakespeare's Globe since Mark Rylance's departure in 2006, also announced that in terms of gender-casting, her first season "will be 50:50 and that's not just small parts played by women or small parts played by men. Across the season the body of work will be equal amounts for male or female. It will be gender blind, race blind, disability blind". ${ }^{7}$ As theatre-makers strive towards greater inclusivity, though, they must also be willing to continually re-evaluate their practices, including their language: almost by definition, calling particular types of casting "blind" is ableist terminology. ${ }^{8}$

7 Stanley Wells comments on how Shakespeare's work, far from being stuck in traditional modes of character representation, is often better able to facilitate what he calls "reversals of conventional expectation": "putting it simply, if audiences can accept the unreality of people on stage talking in verse, they may also be able to accept men as women, women as men, black actors as kings of England, and other apparent anomalies". ${ }^{9}$ Despite this, a variety of negative responses have created substantial media attention around Shakespearean productions and adaptations. In 2016, the casting of Sophie Okonedo as Margaret of Anjou in the BBC's Hollow Crown adaptation caused UKIP Councillor Chris Wood to take to Twitter to register his outrage, writing "So the @BBC has given up on any kind of historical accuracy. How can Margaret of Anjou be played by Sophie Okonedo?" while posting a medieval image of Anjou alongside a photograph of Okonedo. Despite his consternation being caused by an alleged lack of authenticity in the production's casting, the most popular responses to his tweet essentially out-authenticated his views, with David Llewellyn (@TheDaiLlew) noting "The original actor who played Margaret of Anjou had a penis", alluding to the immense likelihood of Shakespeare's original acting company being comprised exclusively of cisgender men; another user, @chevalier_cygne, replied "Hi @CllrChrisWood that's a lovely medieval image you have there. It's from a manuscript that claims M[argaret] of Anjou was descended from a swan". ${ }^{10}$ More recently, Dominic Cavendish wrote an article for The Telegraph entitled "Why 'problematic' Shakespeare is in danger of being cancelled", complaining how:

Over the past few years, Shakespeare performance has increasingly marched to a 'woke' drum. Some would say it has been galvanising, a corrective against conventionality and Bardolatry. We've seen greater diversity in casting and much gender-flipping. Fine, OK. A traditionally cast production is now a rarity, ever more unthinkable. That's less fine. Doesn't it suggest that those getting funds to 
promulgate his work are in some way embarrassed by it, or are so worried about being labelled reactionary - or worse - that they duck the fight? ${ }^{11}$ white playwright is a new way of shifting the British faux-embarrassment that Shakespeare "just happens" to be the world's most famous dramatist. But such an approach belies the fact that Shakespeare's works were used as a colonial educational tool across the world as a justification for white, British, English-speaking cultural superiority and exceptionalism. As powerfully argued by Kimberly Anne Coles, Kim F. Hall, and Ayanna Thompson, "The colonial project is stitched in and through the language and literatures of the pre- and early modern periods; the politics and economics that ultimately produced settler colonialism, chattel slavery, the forced migration of peoples, and the development of the British empire animate these early English texts". ${ }^{12}$ Which is not to place all the crimes of the British empire at Shakespeare's feet, but rather to observe that modern audience members such as Cavendish in search of an "authentic" Shakespearean production will more readily accept modern green fire exit signs in a replica theatre than non-white bodies performing canonical roles upon its wooden stage.

Arguments about who is allowed to participate in Shakespearean endeavours are clearly nothing new. It is worth noting that the proposal of the reconstructed Globe theatre by the American actor Sam Wanamaker was initially met with much British scepticism, with even Southwark council initially declining to support the endeavour. There was, perhaps a sense that Shakespeare and what he stood for had moved on, as actors such as Olivier and Branagh had evolved the idea of Shakespeare into something that captured the new zeitgeist of each generation. "Authenticity", or the recreation of such practices, was derided as being backward-looking, old-fashioned, provincial, irrelevant, and perhaps, ultimately, embarrassing. It presumably could not have helped that the man spearheading the Globe project was American; there was possibly a sense that Shakespeare was not only culturally "claimed" by the British, but also that they wanted to maintain an element of control over how his work was used by others. What this helps bring into focus is that ideas of "authenticity" and "Shakespearean actors" actually have fairly little to do with each other, although it is worth noting that both share charges of elitism and exclusion.

\section{Untangling Ability and Opportunity}

The need for particular skills seems to be one of the principle requirements of a Shakespearean actor, although it is difficult to nail down a precise set of criteria. Nevertheless, the act of performing Shakespeare is seen as a rite of passage, a test exacted of the most promising actors of each age. Max Beerbohm, for instance, wrote of the role of Hamlet as a hoop "through which every very eminent actor must, sooner or later, jump" ${ }^{13}$ Wells attempts to categorise, with corresponding examples, a variety of indicative skills, including voice (noting how Laurence Olivier apparently "spent six months lowering his voice for Othello"), eye movement (such as John Gielgud's ability to produce tears), and breath control (as evidenced by Ellen Terry and Ian Richardson's performance of long verse paragraphs).${ }^{14}$ But Wells is also keen to emphasise that the truly great Shakespearean actors are able to surpass the mastery of a particular skillset and "encompass and weld together the diverse elements of a role [...] It calls in short 
for genius, a quality that we may recognise more easily than we may define". ${ }^{15}$ This seems to be an inherently creative process as well as a skilful one. This act of creation involves an almost literal embodiment of a Shakespeare role, with Wells asserting that "[g]enius is there when an actor appears to be possessed by the character". ${ }^{16}$ This may well be a skill seen as authentically Shakespearean; and a number of scholars have argued that the "more rarified art of 'personation' supersedes actio at some point in the late 1590s", with actors increasingly performing with a sense of "heightened credibility" or "lifelikeness". ${ }^{17}$ This is something which was claimed of Richard Burbage, who "seemed to be experiencing the fluctuating emotions of the characters he portrayed". ${ }^{18}$ It should be noted, however, that the idea of naturalism is necessarily historically contingent, as indeed are emotions and the way they are socially performed.

11 What remains to be acknowledged, however, is the essential layers of privilege which inevitably factor in the careers of the various actors described, traditionally, as being "Shakespearean". Most notably, this privilege comes in the form of opportunity, and these opportunities are generally extended to people who are English-speaking, white, cisgender male, and "able"-bodied. This is not to say that individuals who have been labelled as "Shakespearean actors" have not encountered obstacles such as class, dyspraxia, or dyslexia. But it is hard, for instance, to name many Shakespearean actors with physical disabilities, and despite Wells noting that roles such as Richard III "clearly call for physical transformation", his list of actors consists solely of performers without such disabilities. ${ }^{19}$ In many ways, this is down to a systemic lack of opportunities for actors with disabilities, particularly when being cast in "classic" canonical theatre such as Shakespeare. If anything, it is the apparent metamorphosis of an able-bodied actor into the performance of a "disabled" body that is seen as particularly transcendent in terms of skill, with actors such as Kevin Spacey and Anthony Sher having been praised highly for their portrayals of Richard III while using crutches onstage. More recently, however, Barrie Rutter cast actor Mat Fraser in the title role of his Richard III for Northern Broadsides in 2017. Fraser's mother was prescribed Thalidomide during her pregnancy, resulting in her son's phocomelia condition. Interviewing Fraser for The Guardian, journalist Alfred Hickling writes that "[i]f ever an actor was born to play Richard III it might be Mat Fraser". ${ }^{20}$ Fraser remains a relative outlier in terms of actors with disabilities who are cast in Shakespearean roles, although this may be changing with Terry's "disability-blind" casting at Shakespeare's Globe, which has already seen Deaf actor Nadia Nadarajah as Celia in As You Like It and Guildenstern in Hamlet, to whom I shall return later.

12 As mentioned above, terms such as gender-blind, race-blind, or disability-blind are widely used but increasingly critiqued for two reasons: first, "blind" as a term has connotations of ableism; second, it is impossible not to be aware of gender/race/ disability, and to say we literally cannot see it is to further perpetuate the issues of discrimination which face minority practitioners. Scholars such as Kristin Bria Hopkins instead emphasise the need for "conscious" casting, rather than "blind". Writing on colour-conscious casting in American theatre, she explains:

Under a color-conscious casting policy, race and ethnicity would be a factor that directors, casting teams, and producers must consider during the casting process to encourage more actors of color to audition. Ignoring race in an appearance-based industry, where there is a history of discrimination, only furthers discrimination. ${ }^{21}$ 
Hailey Bachrach has also written about conscious casting, but from a gender perspective. She writes that "gender blind" is:

a phrase that's deployed freely now in discussions about casting, usually referring to women being cast in male roles, usually in plays by Shakespeare and other canonical writers. But it's not used with much consistency: Terry and her company use it to describe their approach to casting, in which both men and women are cast in roles that do not match their own gender, but play them as written. It has also been used to describe casting women in male roles that are then played as women [...] [There is the] suggestion that we do not simply ignore, but literally do not see gender in these productions. ${ }^{22}$

14 As she points out, this is almost never the case: if anything, an audience's awareness of gender is heightened when male actors are cast in traditionally female roles, and vice versa. In the case studies that follow, I consider what it is we are - unwillingly or not drawing attention to when casting productions with a diverse array of performers - by which I mean women in traditionally male roles, people of colour in traditionally white roles, and people with disabilities in any kind of role. To put it more simply: why is representation not enough, and how might theatrical institutions and artistic directors be doing more to embed social injustice than they intend to?

\section{Twelfth Night (dir. Emma Rice, 2017)}

15 If A Midsummer Night's Dream was the flagship production of Emma Rice's first Globe Summer Season in 2016, then 2017's Twelfth Night was undoubtedly intended as a continuation of her theme of irreverence and daring. Both productions seem to have been created with the brief of shaking up Shakespeare and creating a summer festivallike atmosphere in the open-air amphitheatre, replete with vivid costumes, vibrant lighting, and - most controversially of all - bold, amplified music. It seemed to be a deliberate departure from Shakespeare's Globe's aesthetic under Mark Rylance and Dominic Dromgoole, the latter of which was once vexed by Michael Dobson's reference to the Globe as "the folksiest theatre in London"; Dobson notably repeated the claim in an article for Shakespeare Survey in 2015:

The last time I described Shakespeare's Globe as the folksiest theatre in London I received an abusive e-mail from its artistic director, so I am going to do so again just in the hopes of annoying him. For all the rigour and intelligence of its education and research department, for all the talents of some of the theatrical professionals it employs, and for all the cosmopolitanism of its relations with international companies and donors, the default house style at the replica Globe on Bankside has been folksy ever since it opened in $1997 . .^{23}$

Given this history, Emma Rice's approach to her directorship seemed to some an open rebellion. Her first season in 2016 received positive reviews and audience plaudits (in particular, the flagship production of A Midsummer Night's Dream), but equally welldocumented was the internal split it prompted within Shakespeare's Globe itself over the use of un-naturalistic lighting and amplified sound, installed without the permission of the Globe's board or their Architectural Research Group. It is within this context that Rice's second - and final season - played out in 2017, which included her Twelfth Night.

17 Theatre critics were keen to emphasise the production's sense of fun. Matt Trueman gave it four stars in Whatsonstage, writing: 
The play is perfectly present and correct, but it is freely embellished and fulsomely overdone. There are pop songs and dance routines, sometimes even swerves into full-blown musical theatre as composer Ian Ross sets Shakespearean verse to song. We get prat falls and variety turns, big wigs and drag queens, and, as in Kneehigh's work, clownish caricatures instead of credible characters. Sniff if you will. It's a complete blast [...] Anyone still out to spot internal Globe politics will find plenty. Here are conservatives and bohemians at odds with each other - both parties capable of making the other feel small. That's Brexit too, of course: hipster elites and country squares_...] Audiences should take note: drop your guard, forget "proper Shakespeare blah blah" and just enjoy. ${ }^{24}$

18 Aside from his conflation of original practices and a preference for academic rigour with nationalistic jingoism, Trueman emphasizes the party-like atmosphere of the show. Michael Billington was less effusive in The Guardian, arguing that the production never "get[s] to grips with text and character". ${ }^{25}$ Dominic Cavendish in The Telegraph also pointed this out, noting that Shakespeare's text "only sufac[es] about 10 minutes in" to the show. ${ }^{26}$ Reviewing the production for Shakespeare journal, Felicity Brown reflected that the performance "evidenced a medley of innovative and potentially powerful ideas, everywhere underdeveloped and compromised in favour of easy entertainment and laughs". ${ }^{27}$

Perhaps most notably, the cast featured the drag-performer Le Gateau Chocolat as Feste, described in Paul Taylor's review in the Independent as wearing "a dazzling golden kaftan" and "sing[ing] in a resonant bass-baritone as a bearded drag Feste". ${ }^{28}$ Felicity Brown noted that Le Gateau Chocolat "cut the most visually memorable figure in the play, although any political or transgressional resonance of the drag-queen-asfool, having garnered the production publicity, had become implicit to the point of invisibility". ${ }^{29}$ She also notes an interview with Emma Rice in the programme saying "that whatever 'theatrical alchemy' Feste once had with audiences 'is now lost"; as Brown astutely observes, this "proved to be something of a self-fulfilling prophecy, as this Feste was never fully integrated into the action of the drama".$^{30}$ This had also been noted by Michael Billington, who wrote in his review that Feste "is treated as a choric outsider" ${ }^{31}$ In my observation of the production, Feste had essentially been changed from clown to musical scene-changer: rather than interacting and jesting with the ensemble, Le Gateau Chocolat was mostly employed to provide musical numbers which helped the audience shift between scenes and locations. Put simply, this larger than life drag queen, despite having a huge amount of stage time, was - in terms of plot pushed to one side and seemed to be a part of the play's world only in atmosphere. The production's surface-level engagement with LGBTQ representation (via the figure of Le Gateau Chocolat, the singing of gay anthems, and the theme of "what you will" already implied by the play's material), became undermined, as its most obviously visible mascot was not allowed to engage or become fully integrated with the play's community, but was instead marginalised as an entertainment figure and very little more. Such troubled optics are sadly not unusual in mainstream Western theatremaking. As Helen Shaw notes, while the ongoing success of Lin Manuel-Miranda's Hamilton has provided work and exposure for many non-white performers, the high price of tickets has rendered Hamilton's audience demographic more and more elitist:

The orchestra section is now, seemingly, just expense accounts and millionaires and one-show-in-my-lifetime splurgers. Lines like 'Immigrants - they get the job done!' now receive wild applause only from a very specific section of the theater, basically the lottery seats. There's less of the collaborative, 360-degree excitement that characterized it a few years ago, and less of the sense that the audience is pouring 
energy back onto the stage as fast as the cast can ladle it out. 'Here we are in the resistance together' has become 'Entertain us,' which is, considering the respective racial makeups of the audience and cast, troubling. (The mainstream's best trick is that it commodifies even the things that critique it. $)^{32}$

There are a couple of instances in Rice's Twelfth Night where Le Gateau Chocolat was allowed to speak and act rather than just sing. In her mourning clothes, Olivia (Annette McLaughlin) approached Feste after he had soothed her with his singing, and engaged in the following exchange:

OLIVIA. What are you sweet soul? Are you come to save me?

FESTE. I can save no one, lady, not even myself.

OLIVIA. Still your song becalms the storm inside me. My heart is run aground, so will it mend?

FESTE. Anything that is mended is but patched. Virtue that transgresses is but patched with sin. Sin that amends is but patched with virtue. [My emphasis]

21 This last line of Feste's is taken from 1.5 of the Shakespearean text, and I cite the exchange in full here:

OLIVIA. Take the fool away.

FESTE. Do you not hear, fellows? Take away the lady.

OLIVIA. Go to, you're a dry fool, I'll no more of you. Besides, you grow dishonest.

FESTE. Two faults, madonna, that drink and good counsel will amend: for give the dry fool drink, then is the fool not dry; bid the dishonest man mend himself - If he mend, he is no longer dishonest, if he cannot, let the botcher mend him. Anything that's mended is but patched: virtue that transgresses is but patched with sin, and sin that amends is but patched with virtue. If that this simple syllogism will serve, so; if it will not, what remedy? As there is no true cuckold but calamity, so beauty's a flower. The lady bade take away the fool, therefore, I say again, take her away. [My emphasis] (1.5.35-49) 33

As we can see from this side by side comparison, the Feste in Rice's production lost most of his silliness, his quickness, and his verbal dexterity. The cutting of the script meant Le Gateau Chocolat's Feste delivered the line to the grieving Olivia with heaviness, solemnity, and a sense of wisdom hard won by bitter experience. He is given the syllogism of Shakespeare's original lines to speak as if it were sincere, whereas in fact it's essentially clever-sounding gibberish: the sort of line which might be nicely anthologized in isolation but in doing so loses all sense of its original meaning and intention. In making this textual cut, and bestowing the line which remains with gravitas and mysticism as he comforts Olivia rather than teasing her, Rice's production deploys the trope of the "magical negro", a popular mechanism in Hollywood plotlines described by Roxane Gay as "the insertion of a black character into a narrative who bestows upon the protagonist the wisdom he or she needs to move forward in some way". ${ }^{34}$ By inserting additional lines so that Olivia addresses Feste as a "sweet soul" who "becalms the storm inside me", Rice's Twelfth Night - willingly or not - builds Feste into a "magical negro" character who is there to help predominantly white protagonists. A similar moment happens as part of the production's finale, when Malvolio (Katy Owen) fills his pockets with stones and walks into the sea in an apparent suicide attempt, before being rescued by the wise and benign Feste. Shakespeare's text should not be considered sacred, and adding or cutting extra lines or scenes is utterly valid as part of the modern performance tradition. However, if in doing so practitioners create narratives which further marginalise the diverse characters whose stories they claim to be telling, then questions need to be raised about who - other than the white 
practitioners and audiences already privileged by their race within Western culture - is benefiting from modernising Shakespeare in this particular way.

Cast as the twins are Anita-Joy Uwajeh and John Pfumojena. Uwajeh's Viola provided a true defiance to Orsino's misogyny, and Pfumojena's presentation of Sebastian was joyful, although the erotic chemistry between him and Antonio (Pieter Lawman) is strangely lacking. Indeed, early on in the production's run, the two actors shared a passionate kiss in 2.1, but by the time it was recorded for transmission this interaction had been cut. The lasting record of the production, then, provides queer-baiting (the practice of teasing an audience with the hint of homoeroticism without the conviction of openly depicting a gay relationship) rather than queer representation. The problematic erotic politics of Twelfth Night do not end there. While the casting of Uwajeh and Pfumojena as Viola and Sebastian provides Rice's production with two black actors as lead protagonists, the optics this establishes within this story are rather troubling: the black Viola and black Sebastian are lusted after by the white Orsino (Joshua Lacey), and Olivia (Annette McLaughlin) - both of whom also have black servants Curio, Valentine, and Fabian (played by Kandaka Moore, Theo St Claire, and Nandi Bhebhe). This uncannily echoes the plot of a film released earlier in the same year as Rice's Twelfth Night. Jordan Peele's film Get Out portrays the disturbing story of black characters being collected into submissive roles to serve the desires of white masters, exploring the horrors of so-called "benevolent racism" by seemingly progressive white people. In Get Out, a young black photographer named Chris (Daniel Kaluuya) is taken to meet the parents of his white girlfriend Rose (Allison Williams). These parents (Bradley Whitford and Catherine Keener) are keen to emphasise their tolerance and open-mindedness: yes, they have two black servants, Georgina and Walter (Betty Gabriel and Marcus Henderson), but they know how it looks, and treat their charges with dignity and respect. The story's revelation is that Rose has been grooming Chris (as she had groomed Georgina and Walter), becoming romantically involved so that the unsuspecting black love interest can be lured back to the parental home, hypnotised, and auctioned off to the local white community.

The fetishization of Viola (Uwajeh) and Sebastian (Pfumojena) into lust objects by Rice's production, combined with the other black actors in the company being subordinated into service-industry roles (either servants, or - in the case of Feste - entertainers), provides an unnerving parallel with Peele's film that reveals how well-meaning, apparently benevolent white people in positions of power can end up further exacerbating issues of representation. It is also unfortunate that Maria, the only servant-character who is presented with any agency - and is able to marry above her station, thus removing herself from servitude - is played by a white actor (Carly Bawden). Furthermore, the fact that Uwajeh and Pfumojena play characters who are mistaken for each other continues the commonplace racist trope that white people are unable to tell black people apart. The apparent explanation "you all look alike" is something that people of colour experience all too regularly; notably, it happened to Samuel L. Jackson in an interview when the reporter confused him with Laurence Fishburne (Jackson responded "We may all be black and famous but we don't all look alike"). ${ }^{35}$ Unfortunately, the stereotypes in this production are not limited to racial ones, but also extended to the pigeonholing of queer people. Sir Andrew (Marc Antolin) became a lisping, pink sweater-wearing stereotype that the audience was encouraged to laugh at given the slightest opportunity. Described by Paul Taylor in the Independent 
as "so camp and cowardly he'd make John Inman look indecently butch", ${ }^{36}$ the production also amended Andrew's lines to further his campness, changing "I would that I had bestowed that time in the tongues that I have in fencing, dancing, and bearbaiting" to "golfing, dancing, and cross-stitching". The presentation of Andrew in this way not only makes little sense with the story, but it diminishes rather than deepens his characterisation. His main purpose in the ensemble is to provoke laughter, which is the essence of homophobia; he also becomes increasingly clumsy as the production goes on, slipping when he exits the stage and in the fight scene, nearly knocking himself out on the set while wearing comically oversized boxing gloves to make the comparison between traditional masculinity and Andrew's lack of self-control all the more ridiculous. He also gives a deep bow while wearing tight pink briefs with his back to the audience, to raucous laughter as he tries to cover his behind.

This production was ostensibly set in the 1970s, and perhaps this is an excuse for its homophobic and racist stereotypes. The problem is that the audience are laughing at them, not with them, and in a divisive moment for tolerance in Britain it feels deeply uncomfortable. ${ }^{37}$ As Ayanna Thompson writes, "intention, practice, and reception cannot be disentangled: they inform and challenge each other". ${ }^{38}$ In other words, it does not necessarily matter whether or not Rice's casting choices - and the subsequent optics of these choices - were intended to be offensive. But the fact that they can be and were - received as such shows that the production team, for all their apparent championing of diversity, still have much to learn. While this production continued making progress in terms of diversity casting, it must be reiterated that this advancement is negated by the harmful stereotypes the cast were directed to re-create. The production's casting of diverse actors continues to broaden the idea of who is allowed to play Shakespearean roles on a major UK stage; but without "thoughtful diversity" practices theatrical institutions run the risk of re-defining the "Shakespearean actor" in a way which reinforces old prejudices.

\section{Hamlet, Shakespeare's Globe 2018 (dir. Federay Holmes and Elle While)}

One year later and Shakespeare's Globe's main stage is vastly different. Hamlet - which ran in rep with As You Like It, sharing an ensemble cast - was programmed in the first season of Michelle Terry's artistic directorship. The flagship production included no additional scenery, therefore showcasing the bare Globe stage and posing a stark comparison to the ambitious new set-designs that were a signature feature of Rice's artistic tenure. Later on in the production, the Mousetrap section also resists the spectacular: while the dumbshow is fully staged, the play that follows is not. Instead, the play the audience is presented with is the drama of the Elsinore court in the act of watching The Mousetrap. So before the politics of casting in the production are even assessed, a very different tone is being set, comprising more of an anti-spectacle vibe (or, at the very least, a canny re-alignment of perspective) in comparison with the flashy pageantry of Rice's Twelfth Night.

In the Telegraph, Dominic Cavendish wrote that Terry's production of Hamlet was "delivered with the deadpan mischief of school-children who have been asked to re-do their homework in stricter accordance with the teacher's instructions on the blackboard - superficially compliant and yet abounding with provoking surprises" ${ }^{39}$ He goes 
on to describe Emma Rice as "a martyr to the cause of innovation"; then, he claims Terry's productions of Hamlet and As You Like It are "veritable orgies of egalitarianism". ${ }^{40}$ Curiously, Rice's Twelfth Night cast of 13 contained five female actors - plus a deliberately gender ambiguous drag queen, totaling six female or gender nonconforming cast members, which is only one person away from the 50/50 split which Terry implemented. And yet the critical backlash against Terry's strides towards offering opportunity and extending equality showed that derision was more exclusively reserved for Terry, perhaps because her ensemble included multiple cross-gendered casting which refused to adhere to traditional binaries of masculine and feminine.

With Michelle Terry taking the role of Hamlet, Shubham Saraf becoming Ophelia, Bettrys Jones as Laertes, Catrin Aaron as Horatio, and Nadia Nadarajah as Guildernstern, the production shunned traditional notions of gender casting. It is notable that similar casting choices in Rice's Twelfth Night - Katy Owen playing Malvolio in full male clothing and facial hair, and the aforementioned drag Feste - were not considered an "orgy of egalitarianism" by Cavendish's standards in the way that he thought Terry's production clearly was. This may have been largely because the female actor playing Hamlet, male actor playing Ophelia, and female actor playing Laertes in no way hid their physical features. They wore the gendered clothing associated with their character's gender, but Shubham Saraf never wore a wig as Ophelia or attempted to cover his chest hair; Michelle Terry kept her "girlish" chin length curls rather than cutting them off for a more androgynous look, and neither she nor Bettrys Jones lowered their voices in an attempt to seem more "masculine". The distinction between cross-casting in Rice and Terry's productions, then, is one of passing: the ability to convincingly "pass" as a gender which is not the one you were born as. However, the politics of passing, as Jennifer Drouin has shown, replicate pre-existing gender binaries rather than offering a more liberatory approach to identity and its presentation. As Drouin argues, "the concern when passing is to signify not the fluidity of gender, but rather one's firm entrenchment within its fixed sex-derived categories. While drag highlights that all gender is an illusion, the aim of passing is for the illusion to signify as real in the public sphere". ${ }^{41}$ While Rice's production offered cross-casting in the role of Malvolio, critics were more openly troubled by the cross-casting in Terry's Hamlet not merely because of the number of roles cross-cast, but the seeming lack of "passing" by the characters in question. Terry's production did not shy away from presenting its audiences with apparent "incongruities"; for instance, Claudius' line about Hamlet's "unmanly grief" in the second scene may have drawn the attention of some audience members still adapting to seeing Terry herself embody the role. But this is precisely the production's point-of-view: it presents gender presentation itself as a matter of dramatic license.

Despite this, critics were not kind, and some singled out criticism for Terry herself being cast in the titular role. Lloyd Evans, of The Spectator, wrote:

No one but Ms Terry would have hired Ms Terry for this role. She's a decent secondtier actress without any special vocal or physical endowments. Her distinctive features are a toothsome grin and a habit of squinching up her eyes and blinking like an anxious governess unexpectedly robbed of her sunshades while surveying the pyramids. Replacing the prince with a princess costs the play much of its logic, dramatic force and suspense". ${ }^{42}$

Evans' comments on Guildenstern, played by the Deaf actor Nadia Nadarajah, demonstrated his fundamental misreading of one of the production's most moving 
scenes. Hamlet's "O what a piece of work is a man" speech, delivered to Rosencranz and Guildenstern, was simultaneously spoken and signed by Terry's Hamlet, keen to talk to her old school friend in language that they could all understand. Evans described this performance as a "crude lampoon" of sign language, even noting that "there's nothing in the text to suggest that the prince enjoyed poking fun at Elsinore's disabled community". ${ }^{43}$ This only revealed his own ignorance: what he thought was a crude attempt at sign language actually was sign language, and in doing so he denigrated the communication system of a large number of the d/Deaf community.

However, the production itself carefully ensured that the Deaf Guildenstern was never the butt of any jokes. In fact, the show deliberately drew attention to thoughtful use of sign language as the norm, and patronising responses to it as the outlier. For instance, Polonius (Richard Katz) at one point shouts "Well be with you, gentlemen!" because he knows Guildenstern is unable to hear. While the audience responds with laughter, it is clear that we know the joke is on Polonius' insensitivity rather than Guildenstern's Deafness. Similarly, after Rosencranz and Guildenstern have fed back to the king and queen on Hamlet's erratic behaviour, Gertrude's line to Claudius "I shall obey you" is accompanied by mocking bowing gestures miming out the action. As Rosencranz and Guildenstern have just left the scene, there is a sense that Gertrude and Claudius feel free to mock the need to communicate through sign language. This also gets a laugh, although it is less clear whether the audience are laughing at the signing (and the need for it) or laughing at Gertrude and Claudius' tactless mockery. Either way, it shows us that Gertrude and Claudius feel comfortable mocking someone with a disability, which aligns the people who are comfortable with such jokes with the characters we know to be evil or at the very least morally dubious. And in terms of optics, this provides a useful distinction in how to use diverse casting to be on the side of minorities rather than to reinforce oppressive and regressive stereotypes.

One final tweet by way of epilogue. The actor Anjana Vasan, who played Hermia in Rice's 2016 A Midsummer Night's Dream, spoke out after the backlash concerning Rice's tenure: "Feels like 'your Shakespeare doesn't count, your Shakespeare is not our Shakespeare. He was never yours.' Well, keep him. I'm with \#EmmaRice". ${ }^{44}$ If we have criticisms about shaking up Shakespeare for modern audiences, we must be clear in what they are. The furore around Rice's tenure as Artistic Director was presented as a battle between conservative, original practice luddites trying to keep Shakespearean performance from ever changing, and progressive, liberal theatre-makers championing diversity and reflecting modern society. This is a false dichotomy, implying that a critique of sound amplification in an original practice setting runs alongside a refusal to cast non-white, non-diverse actors. My focus in this article is on how we, as academics and practitioners, must make our work progressive and inclusive without reinforcing existing hierarchies or stereotypes. To this end, it should be noted how I have not "re-defined" the term "Shakespearean actor" by the end of this essay. This is because the act of defining a Shakespearean actor is an ongoing process which is never complete; more importantly, it is because if we decide to settle on a new definition we are in danger of inflicting the Derridean kind of violence inherent in the act of naming. To conclusively re-define this term would mark the end of the discussion; rather, "redefining" is a verb which must remain an ongoing action. 


\section{NOTES}

1. Critics have pondered on the origin of this phrase, and whether or not it ever served as a motto for the Globe Theatre. Tiffany Stern finds no link to any theatre before the Restoration, whereas Richard Abrams "favours leaving the case open", Stern, "Was 'Totus mundus agit histrionem' ever the motto of the Globe Theatre?", Theatre Notebook, 51, 1997, 122-127, p. 122; and Abrams, "Oldys, Motteux and 'the Play'rs old motto': the 'Totus Mundus'conundrum revisited", Theatre Notebook, Oct. 2007, 122-131. Either way, the idea behind the phrase (that, as Jacques declares in As You Like It, "All the world's a stage") was a mainstay of early modern thought.

2. "Original practices" refers to work undertaken since the 1990s which strives to replicate the conditions of historical theatre-making such as costumes, cosmetics, lighting, and architecture. The original practices (or "OP") methodology has grown alongside the "Practice-as-research" (or "PAR") movement. As Stephen Purcell notes, these two strategies are alike in their shared experimental nature. See Purcell, "Practice-as-Research and Original Practices", Shakespeare Bulletin, 35.3, 2017, 425-443; and Purcell, "Whose Experiment is it Anyway?: Some Models for Practice-as-Research in Shakespeare Studies" in Stage Matters: Props, Bodies and Space in Shakespearean Performance, eds. Annalisa Castaldo and Rhonda Knight, Fairleigh Dickinson University Press, 2018, 15-33.

3. The capitalized "Deaf" refers to people who have been deaf from birth or from before they started to talk. For Deaf people, sign-language is usually their first language. The non-capitalized "deaf" refers to people who have experienced hearing loss later in life.

4. Stanley Wells, Great Shakespeare Actors: Burbage to Branagh, Oxford, Oxford University Press, 2015, p. 3.

5. Idem, p. 3.

6. Daisy Bowie-Sell, "Michelle Terry: Emma Rice was the best thing that happened to the Globe", Whatsonstage.com (4 January 2018). Accessible online at: https://www.whatsonstage.com/londontheatre/news/michelle-terry-emma-rice-best-shakespeare-globe_45457.html, last accessed 4 June 2020.

7. Mark Brown, "New Shakespeare's Globe chief promises far more diverse casting", The Guardian (18 August 2017). Accessible online at: https://www.theguardian.com/stage/2017/aug/18/newshakespeares-globe-chief-promises-far-more-diverse-casting-michelle-terry, last accessed 4 June 2020.

8. These terms have also been critiqued by Hailey Bachrach, who argues that, far from not seeing gender or race in diverse casting, such practices draw more attention to the construction and representation of gender and race. See Hailey Bachrach, "'Gender blind' casting, who and what goes unseen?", King's English, (23 May 2018). Accessible online at: https://blogs.kcl.ac.uk/english/ 2018/05/23/shakespeare-and-gender/, last accessed 4 June 2020.

9. Wells, op. cit., p. 3.

10. Bethan McKernan, "Ukip councilor attempts to blast BBC for 'historical inaccuracy', gets destroyed by actual historian", Indy 100 (May 2016). Accessible online at: https:// www.indy100.com/article/ukip-councillor-attempts-to-blast-bbc-for-historical-inaccuracy-getsdestroyed-by-actual-historian--ZyZAasU2fb, last accessed 4 June 2020.

11. Dominic Cavendish, "Why 'problematic' Shakespeare is in danger of being cancelled', The Telegraph (9 February 2020). Accessible online at: https://www.telegraph.co.uk/theatre/what-tosee/woke-brigade-close-cancelling-shakespeare/, last accessed 4 June 2020. It is worth noting that the online and print versions of this article were given different titles and illustrated with 
different photographs. The online version of the article was entitled "The woke brigade are close to 'cancelling' Shakespeare", and was originally accompanied by a photo of Deaf actor Nadia Nadarajah performing as Guildenstern in Shakespeare's Globe's Hamlet. This photo was later changed to a portrait of Shakespeare attributed to John Taylor. The print version of the article was illustrated with a photograph of Rosie Sheehy playing the role of King John for the RSC. The respective differences between editions is likely due to the online version wanting to deliberately court controversy as a means of driving-up how many times the article is shared and discussed (known as "click-baiting"). Using Nadarajah's image in the original version of the online edition ("The woke brigade are close to 'cancelling' Shakespeare") aligns a female actor of colour who has a disability with the idea that so-called "traditional" Shakespeare is being eroded, implying that the blame for this falls on the shoulders of people like Nadarajah.

12. Kimberly Anne Coles, Kim F. Hall, and Ayanna Thompson, "BlacKKKShakespearean: A Call to Action for Medieval and Early Modern Studies', MLA Profession, November 2019, accessible online at: https://profession.mla.org/blackkkshakespearean-a-call-to-action-for-medieval-and-earlymodern-studies/, last accessed 4 June 2020.

13. Beerbohm, as cited in Wells, op. cit., p. 2.

14. Wells, op. cit., p. 6-7.

15. Wells, op. cit., p. 8.

16. Wells, op. cit., p. 9.

17. Travis Curtwright, Shakespeare's Dramatic Persons, Maryland and London, Fairleigh Dickinson University Press, 2017, p.77. Among the scholars Curtwright cites are Andrew Gurr, Jane Donawerth, Robert Weimann, and Douglas Bruster.

18. Wells, op. cit., p. 19.

19. Wells, op. cit., p. 4.

20. Alfred Hickling, "Mat Fraser on playing Richard III: 'I'd begun to feel like yesterday's cripple"', The Guardian (8 May 2017). Accessible online at: https://www.theguardian.com/stage/ 2017/may/08/mat-fraser-interview-richard-iii-disability-northern-broadsides, last accessed 4 June 2020.

21. Kristin Bria Hopkins, "There's No Business Like Show Business: Abandoning Color-Blind Casting and Embracing Color-Conscious Casting in American Theatre", Journal of Sports and Entertainment Law, 9.2, Spring, 2018, 131-156, p. 131.

22. Hailey Bachrach, “'Gender blind' casting, who and what goes unseen?", King's English, (23 May 2018), accessible online at: https://blogs.kcl.ac.uk/english/2018/05/23/shakespeare-andgender/, last accessed 4 June 2020.

23. Michael Dobson, "Shakespeare and the Idea of National Theatres", Shakespeare Survey 68, 2015, 234-246, p. 242.

24. Matt Trueman, "Review: Twelfth Night (Shakespeare's Globe)", Whatsonstage.com (25 May 2017), accessible online at: https://www.whatsonstage.com/london-theatre/reviews/twelfthnight-shakespeares-globe-emma-rice_43684.html , last accessed 4 June 2020.

25. Michael Billington, "Twelfth Night review - Emma Rice's Highland fling brings that sinking feeling”, The Guardian (25 May 2017), accessible online at: https://www.theguardian.com/stage/ 2017/may/25/twelfth-night-review-emma-rice-disco-party-shakespeares-globe , last accessed 4 June 2020.

26. Dominic Cavendish, “Emma Rice's superbly defiant farewell to the Globe - Twelfth Night, Shakespeare's Globe review", The Telegraph (25 May 2017), accessible online at: https:// www.telegraph.co.uk/theatre/what-to-see/emma-rices-defiant-farewell-twelfth-night-globereview/, last accessed 4 June 2020.

27. Felicity Brown, "Review of Shakespeare's Twelfth Night (directed by Emma Rice) at Shakespeare's Globe, 24 May 2017', Shakespeare, 13.4, 2017, 359-361, p. 359. 
28. Paul Taylor, “Twelfth Night, Shakespeare's Globe, London, review: Gleefully defiant irreverence is the prevailing mood from the outset", The Independent (25 May 2017), accessible online at: https://www.independent.co.uk/arts-entertainment/theatre-dance/reviews/twelfthnight-review-a7755216.html, last accessed 4 June 2020.

29. Brown, art. cit., p. 359.

30. Idem, 359.

31. Billington, art. cit..

32. Helen Shaw, "The Book of Mormon and Hamilton already feel like they're from another time", Vulture (16 December 2019), accessible online at: https://www.vulture.com/2019/12/rereviewing-the-book-of-mormon-and-hamilton-in-2019.html, last accessed 4 June 2020.

33. William Shakespeare, Twelfth Night, ed. Keir Elam, coll. Arden Shakespeare 3, London, Bloomsbury, 2008.

34. Roxane Gay, "The Solace of Preparing Fried Foods and Other Quaint Remembrances from 1960s Mississippi: Thoughts on The Help', in Bad Feminist, New York, Corsair, 2014. The term "magical negro" is originally coined by Matthew Hughey in "Cinethetic Racism: White Redemption and Black Stereotypes in 'Magical Negro' Films”, Social Problems, 56.3, August 2009, 543-577.

35. Joseph Harker, 'It's not just Samuel L Jackson - we've all had those 'we all look alike' moments", The Guardian (12 February 2014), accessible online at: https://www.theguardian.com/ commentisfree/2014/feb/12/samuel-l-jackson-laurence-fishburne-black-outsider, last accessed 4 June 2020.

36. Taylor, art. cit..

37. Since 2014, hate crimes against gay and lesbian people have doubled in the UK, and have trebled for transgender people. See Sarah Marsh, Aamna Modhin, and Niamh McIntyre, "Homophobic and transphobic hate crimes surge in England and Wales", The Guardian (14 June 2019), accessible online at: https://www.theguardian.com/world/2019/jun/14/homophobic-andtransphobic-hate-crimes-surge-in-england-and-wales, last accessed 4 June 2020. In terms of racism in the UK, recent data maintains the sharp inequalities faced by marginalised ethnicities. See Anthony Cuthbertson, "Eleven charts that show extent of racial inequality in the UK", The Independent (18 June 2020), accessible online at https://www.independent.co.uk/news/uk/homenews/racism-uk-inequality-black-lives-matter-wealth-economic-health-a9567461.html

38. Ayanna Thompson, Passing Strange: Shakespeare, Race, and Contemporary America, Oxford, Oxford University Press, 2011, p. 113.

39. Dominic Cavendish, "Hamlet and As You Like It review, Shakespeare's Globe: the good, the bad, and the plain cuckoo", The Telegraph (18 May 2018), accessible online at: https:// www.telegraph.co.uk/theatre/what-to-see/hamlet-like-review-shakespeares-globe-good-badplain-cuckoo/ , last accessed 4 June 2020.

40. Ibid.

41. Jennifer Drouin, "Cross-Dressing, Drag, and Passing: Slippages in Shakespearean Comedy", in James C. Bulman (ed.) Shakespeare Re-Dressed: Cross-Gender Casting in Contemporary Performance, Fairleigh Dickinson University Press, 2008, 23-53, p. 30.

42. Lloyd Evans, "Return to gender: Replacing the prince with a princess costs the play much of its logic, dramatic force and suspense", The Spectator (2 June 2018), accessible online at: https:// www.spectator.co.uk/2018/06/no-one-but-michelle-terry-would-have-hired-michelle-terry-toplay-hamlet/, last accessed 4 June 2020.

43. Ibid..

44. Anjana Vasan (@aj_vasan), Twitter.com (25 October 2016), accessible online at: https:// twitter.com/aj_vasan/status/790858861582450689, last accessed 4 June 2020. 


\section{ABSTRACTS}

This paper evaluates casting practices at Shakespeare's Globe under the artistic directorships of Emma Rice (2016-17) and Michelle Terry (2018-) in the context of diversity. It explores the casting and subsequent optics of two productions: Rice's Twelfth Night in 2017, and Terry's Hamlet the following year. I argue that traditional ideas of the "Shakespearean actor" have shifted in an age where companies move towards greater inclusivity, allowing for more diverse casting of people of colour, people with disabilities, and cross-gender casting. Through the processes of embodiment, these casting choices add paratextual readings onto productions, which can provide improved agency for traditionally-marginalised communities, but can also replicate problematic readings. In essence, this article argues that diverse casting practices alone are not enough to provide opportunity and agency for underrepresented identities in theatrical productions. If such diverse casting practices are happening - which they should - then care must be taken not to perpetuate out-dated and harmful stereotypes of Black, disabled, and/or queer people. Inclusive casting fails in its aims if it reduces already marginalised people to the margins yet further, therefore representation onstage is not enough: the stories that these bodies tell must be empowering before the bodies themselves can be empowered.

Cet article évalue les pratiques de distribution d'acteurs au Théâtre du Globe de Shakespeare, sous les directions artistiques d'Emma Rice (2016-17) et de Michelle Terry (2018-) sous l'angle de la diversité. Il explore la distribution et l'optique dans laquelle deux mises en scène ont été montées: La Nuit des Rois, par Emma Rice en 2017, et Hamlet, par Michelle Terry en 2018. Je postule que les idées traditionnelles sur ce qu'est l'«acteur shakespearien " ont évolué à une époque où les compagnies théâtrales s'engagent à être plus inclusive, ce qui permet une distribution des rôles plus diverse avec des gens de couleurs, des handicapés, une distribution non genrée. À travers les processus d'incarnation, ces choix de distribution ajoutent aux mises en scènes des lectures paratextuelles qui peuvent fournir aux communautés traditionnellement marginalisées une agentivité renforcée mais aussi reproduire des lectures problématiques. Au fond, cet article avance l'idée que les seules pratiques de distribution de la diversité ne suffisent pas à fournir l'occasion et l'agentivité aux identités sous-représentées dans les spectacles de théâtre. Si de telles pratiques de distribution ont lieu - ce qui devrait être le cas - alors il faut veiller à ne pas perpétuer des stéréotypes obsolètes et nuisibles de Noirs, de handicapés et/ou de personnes queer. Une distribution inclusive manque son but si elle renvoie aux marges des gens déjà marginalisés. Aussi, la représentation sur scène de ces personnes n'est pas suffisante : les histoires que ces corps racontent doivent être source de pouvoir avant que les corps eux-mêmes en soient dotés.

\section{INDEX}

Keywords: Acting, disability, embodiment, gender, intention, optics, performance studies, privilege, race

Mots-clés: Jeu d'acteur, handicap, incarnation, genre, intention, optique, représentation théâtrale, privilège, race 
AUTHOR

MIRANDA FAY THOMAS

Trinity College Dublin 